\title{
Notícias Bibliogräficas
}

\author{
Beagleohole, R.; Bonita, R.; Kjellström, T, - Epidemiologia básica. Washington, D.C., \\ Organización Panamericana de Salud, 1994. 186p.
}

Este livro constitui a tradução do original em língua inglesa editado em 1993 pela Organização Múndial da Saúde. Como o título indica, objetiva fornecer os elementos epidemiológicos básicos. Com tal finalidade, o texto é dividido em 11 Capítulos e três Anexos. Procurando obedecer a determinada seqüência, o tema, exposto nos quatro primeiros capítulos, inicianse com a definiçāo de epidemiologia, seguindo-se a metodologia e incluindo noçōes de estatística. Prosseguindo, o Capítulo 5 é dedicado à conceituação de causalidade enquanto o sexto trata da pevenção. Do Capítulo $7 \mathrm{em}$ diante o texto especializa-se, tratando de doenças transmissíveis, a chamada epidemiologia clínica, a ambiental e, finalmente abordando aspectos de operacionalizaçâo e aprendizado. Aliás, neste último sentido, a preocupaçāo didática do livro reflete-se nas questōes a serem respondidas e colocadas no finalde cada Capítulo.

Essa disposição da temática tem, por finalidade, dar orientação de aprendizado ao texto. Não obstante, alguns Capítulos bastante heterogêneos. Em particular, o referente aos tipos de estudo (Capítulo 3 ), no qual se inclui os processos observacionais juntamente com os experimentais. $O$ tratamento desses assuntos, em número limitado a cerca de 24 páginas, toma-o forçosamente perfunctório. Deixa assim de ter a ênfase que the deveria ser dada em livro desta natureza. Em contrapartida, observa-se maior preocupação em abordar os potenciais de aplicabilidade, como se verifica a partir da segunda metade do texto (Capítulo 6 em diante). Isso desenha o perfil da obra como precipuamente endereçado aos engajados na prática de saúde pública. E essa feição torna-se tanto mais evidente ao se levar conta os assuntos abordados nos Capítulos 8,9 e 10, ou seja, a clínica, o ambiente, o meio ocupacional, os serviços de saúde e a política sanitária.

Em decorrência, há que se concluir que se trata de um livro útil para os que militam nas atividades de saúde pública. Nesse sentido, constitui-se em instrumento útil para o aprendizado dos fundamentos epidemiológicos necessários às lides profissionais. Por outro lado, não se trata de obra de consulta para a pesquisa científica. Eis que os que nela se engajam têm, por sabidas, noçőes que o livro apresenta.

Assinala-se, por de apreciável interesse, a relação de periódicos especializados em epidemiologia constante como Anexos 2 e 3 . Este último dedicado àqueles de língua hispânica (embora inclua esta Revista de Saúde Pública).

Em resumo, trata-se de obra de utjlidade para os administradores em saúde pública que desejem recordar as noçỏes essenciais de epidermiologia

Oswaldo Paulo Forattini Departamento de Epidemiologia Faculdade de Saúde Pública da USP 